\title{
COMPLIANCE OF SURGICAL HAND SCRUB IN OPERATION THEATRE OF TEACHING HOSPITAL, CHITWAN \\ Anisha Paudel ${ }^{1, *}$, Bishnu Bista $^{2}$ \\ ${ }^{1}$ School of Nursing, Chitwan Medical College, Bharatpur, Chitwan, Nepal
}

\begin{abstract}
Received: 12 Oct, 2018
Accepted: 18 March, 2019

Published: 31 March, 2019

Key words: Compliance; Operation Theatre; Surgical hand Scrub.

*Correspondence to: Anisha Poudel, School of Nursing, Chitwan Medical College, Bharatpur 10, Chitwan, Nepal Email: anisha.poudel111@gmail.com
\end{abstract}

\section{Citation}

Paudel A, Bista B. Compliance of surgical hand scrub in operation theatre of teaching hospital, Chitwan. Journal of Chitwan Medical College. 2019; 9 (27): 36-40.

\section{Peer Reviewed}

\section{INTRODUCTION}

Hand Hygiene is the least expensive and most effective factors in preventing and controlling the transmission of pathogens within health care settings. ${ }^{1}$ The hands of health workers play an important role in transmission of the health care associated pathogens from one patient to another. ${ }^{2}$ Health care associated infection due to poor hand hygiene is a major cause of increasing morbidity, mortality and health care costs among hospitalized patient worldwide. ${ }^{3}$

Globally, surgical site infection (SSI) rates have been reported range of $2.5 \%$ to $41.9 \%$ with significantly higher rates in developing countries. ${ }^{4} \mathrm{SSI}$ is the results from multiple factors related to patient, surgeon and health care environment. European Centre for Disease Prevention and Control 2015 reported $1.88 \%$ SS. In Nepal, SSI was reported about 
3.99\% among 92,41,979 cases. ${ }^{5}$ SSI's leads to prolong hospitalization, financial burden, reoperation, readmission and increase mortality rates. ${ }^{6}$

Surgical hand scrubbing is essential in order to eliminate the transient flora and reduce the resident flora. ${ }^{7}$ Surgical hand scrubbing is an extension of hand washing with antimicrobial soap and water before donning surgical attire pre-operatively. ${ }^{1,8}$ Jewellery and nails can be the source of microbial transmission so it is mandatory to remove jewellery, artificial nails or nail polish and to keep nails short before surgical hand preparation. ${ }^{1}$

Before each operation, entire surgical team should scrub their hands and arms to the elbow. The first scrub of the day is longer i.e. minimum 5 minutes than any subsequent scrubs between consecutive clean operations i.e. minimum 3 minutes. ${ }^{9}$ The most commonly use products for surgical hand antisepsis is chlorhexidine or povidine-iodine containing soaps.1 Abdollahi et al. ${ }^{10}$ found that compliance with scrub prerequisites $58 \%$, scrub process $68 \%$, 2 minutes scrub time $22 \%$ and scrub equipments $55 \%$ in pre-test. Dhakal, Angadi \& Lopchan ${ }^{11}$ claimed that nurses $(4.29 \%)$ on operation theatre did not scrub hands well to two inch above the elbow and completed the procedure less than 3 to 5 minutes.

Despite the considerable advancement in surgery, post-surgery infection still is one of the causes of mortality and surgical team hands are one of the most important causes of these infections and studies shown that the compliance of surgical hand scrub is not adequate even after the intervention. So, it significant to identify the level of compliance of surgical hand scrubs among the surgical team in Operation Theatre of Teaching Hospital, Chitwan.

Observational study found surgical scrubbing practices was $75.1 \%$ adequate among nurses which concluded that nurse's still need more training to achieve excellence in this area ${ }^{12}$ so that surgical hand preparation is use to prevent surgical site infection.7 Hence the objective of the study was to evaluate the compliance of surgical hand scrub among surgical team in Operation Theatre of Teaching Hospital, Chitwan.

\section{METHODS}

A descriptive cross-sectional study was conducted at Operation Theatre, Chitwan Medical College, Chitwan, Nepal from 20th June to 4th July, 2018 $A D$ after getting ethical clearance from CMC-IRC. The total of sixty-nine respondents from surgical team included surgeons $(n=27)$, residents surgery $(n=9)$, interns $(n=10)$ and registered Nurses $(n=23)$ who were selected by non-probability consecutive sampling technique.

The study instrument was an observational checklist with Yes- No questions. The checklist developed based on the standard tool. ${ }^{1,8}$ The observation check list of compliance of surgical hand scrub (scrub pre requisites, scrub process and scrub time) consisted 22 items. Each item in checklist rated Yes for scored ' 1 ' and No for scored ' 0 '. Level of compliance was measured by calculating the total score in terms of percentage.

Data collection was done through observation method. One participant was observed once a time; they were excluded if they scrub next time. To describe the results, the descriptive and inferential statistics were used by the IBM SPSS version 20 .

\section{RESULTS}

Table 1 shows that among the 69 respondents, majority of males (53.6\%), surgeons $(39.1 \%)$ and they $(47.8 \%)$ had job experience of $1-5$ years. Most of the surgical hand scrub was observed in morning shift (69.6\%).

Table 1: Demographic Information of the Respondents $(n=69)$

\begin{tabular}{|c|c|c|}
\hline Variables & Number & $\%$ \\
\hline \multicolumn{3}{|l|}{ Sex } \\
\hline Male & 37 & 53.6 \\
\hline Female & 32 & 46.4 \\
\hline \multicolumn{3}{|l|}{ Profession } \\
\hline Registered Nurse & 23 & 33.3 \\
\hline Surgeon & 27 & 39.1 \\
\hline Resident (Surgery) & 9 & 13 \\
\hline Intern (MBBS) & 10 & 14.5 \\
\hline \multicolumn{3}{|l|}{ Education } \\
\hline Proficiency Certificate Level & 21 & 30.4 \\
\hline Bachelor & 21 & 30.4 \\
\hline Post Graduate & 21 & 30.4 \\
\hline
\end{tabular}




\begin{tabular}{|c|c|c|}
\hline Super Speciality & 6 & 8.7 \\
\hline \multicolumn{3}{|l|}{ Job Experience } \\
\hline$<1$ year & 28 & 40.6 \\
\hline 1-5 years & 33 & 47.8 \\
\hline $6-10$ years & 8 & 11.6 \\
\hline \multicolumn{3}{|l|}{ Working Shift } \\
\hline Morning & 48 & 69.6 \\
\hline Evening & 21 & 30.4 \\
\hline
\end{tabular}

$65.2 \%$ performed rotational rubbing backwards and forwards with clapsed finger of right hand into left hand and vice versa, $46.4 \%$ continued with rotational action down opposing arms working to the elbow for 1 minutes. $88.4 \%$ of respondents rinsed hands and arms by passing them through the water from fingertips to elbow and $85.5 \%$ hold the hands above the elbow at all the times. Only, $7.2 \%$ of respondents moved their arms back and forth through the water and $5.8 \%$ splashed water onto their dress.

Table 2: Utilization of Scrub Pre requisites for the Surgical Hand Scrub $(n=69)$

\section{Table 3: Scrub Process Domain related to Surgical Hand Scrub $(n=69)$}

\begin{tabular}{|c|c|c|}
\hline \multirow[t]{2}{*}{ Items of Scrub Pre requisites } & \multicolumn{2}{|c|}{\begin{tabular}{|l} 
Performed \\
activities \\
\end{tabular}} \\
\hline & $\begin{array}{l}\text { YES } \\
(\%) \\
\end{array}$ & $\begin{array}{l}\text { NO } \\
(\%)\end{array}$ \\
\hline $\begin{array}{l}\text { Wear surgical cap and face mask } \\
\text { correctly }\end{array}$ & \begin{tabular}{|l|}
38 \\
$(55.1)$ \\
\end{tabular} & \begin{tabular}{|l|}
31 \\
$(44.9)$ \\
\end{tabular} \\
\hline Keeps nails short* & \begin{tabular}{|l|}
68 \\
$(98.6)$ \\
\end{tabular} & \begin{tabular}{|l|l|}
1 \\
$(1.4)$ \\
\end{tabular} \\
\hline $\begin{array}{l}\text { Remove nail polish, artificial nails } \\
\text { and all jewellery (rings, watch, } \\
\text { bracelets) } *\end{array}$ & $\begin{array}{l}67 \\
(97.1)\end{array}$ & $\begin{array}{l}2 \\
(2.9)\end{array}$ \\
\hline $\begin{array}{l}\text { Be sure about availability of soap, } \\
\text { povidine iodine } 7.5 \% \text { and sterile } \\
\text { gown and gloves. }\end{array}$ & $\begin{array}{l}47 \\
(68.1)\end{array}$ & $\begin{array}{l}22 \\
(31.9)\end{array}$ \\
\hline $\begin{array}{l}\text { Wash hands and arms with soap if } \\
\text { hands are visibly soiled }\end{array}$ & \begin{tabular}{|l}
64 \\
$(92.8)$ \\
\end{tabular} & \begin{tabular}{|l}
5 \\
$(7.2)$ \\
\end{tabular} \\
\hline $\begin{array}{l}\text { Start timing either through wall } \\
\text { clock or scrub sink timer. }\end{array}$ & $6(8.7)$ & \begin{tabular}{|l}
63 \\
$(91.3)$
\end{tabular} \\
\hline
\end{tabular}

\section{*Critical steps}

Table 2 presents that only $55.1 \%$ of respondents wore surgical cap and face mask correctly where $2.9 \%$ performed surgical hand scrub without removing nail polish and jewellery. Before proceeding for surgical hand scrub, $68.1 \%$ were ensured about the availability of soap, povidine iodine $7.5 \%$ and sterile gown and gloves. Most of them (92.8\%) washed hands and arms with soap if hands were visibly soiled. Very limited respondents (8.7\%) used follow the principal of starting timer of scrub sink.

Table 3 presents that $98.6 \%$ of respondents applied sufficient amount of povidine iodine $7.5 \%$ from dispenser, $89.9 \%$ scrubbed right palm over back of left hand and vice versa with finger interlaced,

\begin{tabular}{|c|c|c|}
\hline \multirow[t]{2}{*}{ Items of Scrub Process } & \multicolumn{2}{|c|}{$\begin{array}{l}\text { Performed } \\
\text { activities }\end{array}$} \\
\hline & $\begin{array}{l}\text { YES } \\
(\%)\end{array}$ & NO (\%) \\
\hline $\begin{array}{l}\text { Apply appropriate amount }(5 \mathrm{ml}) \\
\text { of scrub solution (Povidione } \\
\text { iodine } 7.5 \% \text { ) from dispenser }\end{array}$ & $\begin{array}{l}68 \\
(98.6)\end{array}$ & $1(1.4)$ \\
\hline $\begin{array}{l}\text { Scrub right palm over back of } \\
\text { left hand and vice versa with } \\
\text { fingers interlaced }\end{array}$ & $\begin{array}{l}62 \\
(89.9)\end{array}$ & $7(10.1)$ \\
\hline $\begin{array}{l}\text { Rub palm to palm, finger inter- } \\
\text { laced }\end{array}$ & $\begin{array}{l}59 \\
(85.5)\end{array}$ & $\begin{array}{l}10 \\
(14.5)\end{array}$ \\
\hline $\begin{array}{l}\text { Rotational rubbing backwards } \\
\text { and forwards with clapsed finger } \\
\text { of right hand into left hand and } \\
\text { vice versa }\end{array}$ & $\begin{array}{l}45 \\
(65.2)\end{array}$ & $\begin{array}{l}24 \\
(34.8)\end{array}$ \\
\hline $\begin{array}{l}\text { Rotational rubbing of right } \\
\text { thumb clasped in left hand and } \\
\text { vice versa }\end{array}$ & $\begin{array}{l}56 \\
(81.2)\end{array}$ & $\begin{array}{l}13 \\
(18.8)\end{array}$ \\
\hline $\begin{array}{l}\text { Rub fingertips on palms for both } \\
\text { hands. }\end{array}$ & \begin{tabular}{|l|}
30 \\
$(43.5)$ \\
\end{tabular} & $\begin{array}{l}39 \\
(56.5) \\
\end{array}$ \\
\hline $\begin{array}{l}\text { Continue with rotational action } \\
\text { down opposing arms working to } \\
\text { the elbow for } 1 \text { minute. } *\end{array}$ & $\begin{array}{l}32 \\
(46.4)\end{array}$ & $\begin{array}{l}37 \\
(53.6)\end{array}$ \\
\hline $\begin{array}{l}\text { Rinse hands and arms by passing } \\
\text { them through the water in one } \\
\text { direction; only from fingertips to } \\
\text { elbow* }\end{array}$ & $\begin{array}{l}61 \\
(88.4)\end{array}$ & $\begin{array}{c}8 \\
(11.6)\end{array}$ \\
\hline $\begin{array}{l}\text { Do not move the arms back and } \\
\text { forth through the water }\end{array}$ & $\begin{array}{l}64 \\
(92.8)\end{array}$ & $5(7.2)$ \\
\hline $\begin{array}{l}\text { Do not splash the water onto } \\
\text { the dress }\end{array}$ & $\begin{array}{l}65 \\
(94.2) \\
\end{array}$ & $4(5.8)$ \\
\hline $\begin{array}{l}\text { Hold the hands above the elbow } \\
\text { at all the times* }\end{array}$ & $\begin{array}{l}59 \\
(85.5)\end{array}$ & $\begin{array}{l}10 \\
(14.5)\end{array}$ \\
\hline
\end{tabular}




\begin{tabular}{|l|l|l|}
\hline $\begin{array}{l}\text { Grasp sterile towel and back } \\
\text { away from sterile field }\end{array}$ & $\begin{array}{l}69 \\
(100)\end{array}$ & \\
\hline $\begin{array}{l}\text { Use one side of towel to dry one } \\
\text { hand from fingertip to elbow }\end{array}$ & $\begin{array}{l}63 \\
(91.3)\end{array}$ & $6(8.7)$ \\
\hline $\begin{array}{l}\text { Use opposite side of towel to } \\
\text { dry another hand from fingertip } \\
\text { to elbow }\end{array}$ & $\begin{array}{l}63 \\
(91.3)\end{array}$ & $6(8.7)$ \\
\hline $\begin{array}{l}\text { Do not repeat to an area of skin } \\
\text { once it has blotted dry }\end{array}$ & $\begin{array}{l}48 \\
(69.6)\end{array}$ & $\begin{array}{l}21 \\
(30.4)\end{array}$ \\
\hline
\end{tabular}

${ }^{*}$ Critical steps

Table 5 shows that most of the respondents (87\%) did not compliance surgical hand scrub before proceeding to surgical procedure based on criteria.

Table 5: Items of Scrub time and Level of Compliance on Surgical Hand Scrub among Surgical Team $(n=69)$

\begin{tabular}{|l|l|l|}
\hline \multicolumn{2}{|c|}{ Items of Scrub Time } & \multicolumn{2}{l|}{$\begin{array}{l}\text { PERFORMED AC- } \\
\text { TIVITIES }\end{array}$} \\
\cline { 2 - 3 } & YES (\%) & $\begin{array}{l}\text { NO } \\
(\%)\end{array}$ \\
\hline $\begin{array}{l}\text { Complete the first scrub } \\
\text { of the day within 5 min- } \\
\text { utes and other consecu- } \\
\text { tive scrub within 3 minutes* }\end{array}$ & $\begin{array}{l}50 \\
(72.5)\end{array}$ & \\
\hline $\begin{array}{l}\text { Overall Level of Compliance on Surgical Hand } \\
\text { Scrub among Surgical Team n=69 }\end{array}$ & NUMBER & $\begin{array}{l}\text { PER- } \\
\text { CENT- } \\
\text { Level of compliance }\end{array}$ \\
\hline \begin{tabular}{l} 
LeE \\
\hline Good
\end{tabular} & 9 & 13 \\
\hline Poor & 60 & 87 \\
\hline Total & 69 & 100 \\
\hline
\end{tabular}

Mean+ SD $=17.87+3.41$, maximum possible score: 22, Obtained score: $8-21$

\section{Key points:}

$>90 \%$ without missing critical steps $=$ Good level of compliance

$<90 \%$ with or without missing critical steps $=$ Poor level of compliance

\section{DISCUSSION}

Surgical hand scrub is an essential component of everyone who involved in operative procedures. Improper hand scrubs facilitate to carry microbes so that surgical hand scrub is significant to prevent surgical site infection. Results of the present study showed considerable lacking in the surgical scrub of the studied hospital. Compliance with the scrub time standards had the lowest score $(27 \%)$.

Several studies of similar type have shown that significance dissimilarities of level of surgical hand scrub compliance. ${ }^{4,6,10,12-14}$ This study found that only $13 \%$ of respondents had compliance the surgical hand scrub according to the standard checklist criteria of (more than 90\% score without missing critical steps).

Hospital has policy to wear mask, cap, remove artificial jewelleries, nail police, certain of scrub materials and start sink timer before scrub process. Lack of awareness about hospital policy results variations in scrub practice. It is important to provide documented policy to improve compliance and to prevent post-surgery infections.

There were several lacking in the process of the observed scrubs in this study. Alaa-Eldeen, Saad \& Elreface $^{15}$ mentioned that only $46.7 \%$ nurses performed the principles of aseptic technique in wearing mask, gowning, gloving and scrubbing correctly. It might be due to lack of in-service training for the surgical team. A study in King Khalid hospital, Najran found that $84.9 \%$ of surgical team scrubbed hands and forehand and dried them correctly. ${ }^{14}$ Jeyakumar, Sabu \& Segeran ${ }^{12}$ revealed that the adequacy of scrubbing was very good $(75.1 \%)$. The strict implementation of protocol and continuous inhouse skill training, providing feedback enhance the higher compliance of surgical hand scrub. ${ }^{1,17}$

According to hospital policy, the standard time for the first scrub was 5 minutes and for the second scrub was 3 minutes. However, observations of this study found that only $17.5 \%$ respondents could follow the duration of scrub in the first and second as per determined criteria. Utilization of time in terms of both over- scrubbing and under scrubbing can increase the risk of transmitting infection so it is better for the scrubbers to follow the rules. ${ }^{13,16}$

\section{CONCLUSION}

This study observed the surgical hand scrub in 
the Operation Theatre of teaching hospital in the real situation. The results showed considerable noncompliance in the scrub of studied hospital. Yet, the gap between compliance scores, still there is potentiality for improvement in all dimensions. Based on the study findings, periodical audit of the surgical hand scrub in the operation theatre to see whether it complies with the standards or not and to find out the problems to be solved through hands on skill education.

\section{REFERENCES}

1. WHO Guidelines on Hand Hygiene in Health Care. (2009). Retrivedhttp.who.int/iris/bitstream/ handle/10665/44102/9789241597906_eng.pdf

2. Joshi, S.K., Joshi, A. Park, B.J.\& Aryal, U.R. (2013). Hand washing practice among health workers in a Teaching Hospital. JNHRC, 11(23), 1- 5. https:// doi.org/10.33314/jnhrc.353

3. Sydnor ER, Perl TM. Hospital epidemiology and infection control in acute-care settings. Clinical microbiology reviews. 2011 Jan 1;24(1):141-73. https://dx.doi.org/10.1128/CMR.00027-10

4. 4. Asaad, A. M., \& Badr, S. A. (2016). Surgical Site Infection in Developing Countries: Current burden and future challenges. Clinical Microbiology: Open Access, 5(6). doi: 10.4172/2327-5073.1000e13

5. Department of Health Services DOHS. (2072/73). Annual Report. Government of Nepal. Ministry of Health. Kathmandu

6. Bhasme, A. S., Menezes, R. J., D'souza, T., \& Ipe, J. (2017). Duration of surgical hand scrub in orthopaedic surgeries. International Journal of Orthopaedics Sciences, 3(3), 34- 36. http:// dx.doi.org/10.22271/ortho.2017.v3.i3a.08

7. WHO Global guidelines for the prevention Surgical Site Infection. (2016). Retrived from www.who.int/en/news-room/detail/03-112016-who-recommends- 29-ways-to-stopsurgical-infections

8. Association for Perioperative Practice 2007. Standards and Recommendations for Safe
Perioperative Practice Harrogate, AfPP

9. WHO Best Practice Protocols Clinical Procedures Safety.(2007). Retrived www.who.int/surgery/ publication/BestPracticeProtocolsCPSafety.pdf

10. Abdollahi L, Tabrizi JS, Jodati A, Safaie N, MoradiJoo M, Daemi A. Quality of surgical scrub in a heart hospital: Do not take it for granted. Journal of cardiovascular and thoracic research. 2017;9(3):164.

11. Dhakal B, AngadiS, Lopchan M. Nurses' knowledge and practice of aseptic technique in the operation theatre at selected hospitals of Bharatpur. International Archives of BioMedical and Clinical Research. 2016 Jun 18;2(2):32-4. https://dx.doi. org/10.5958/2454-2660.2016.00050.8

12. Jeyakumar, A. K., Sabu, S., \& Segeran, F. (2017). Adequacy of scrubbing, gowning and gloving among operation room IOSR Journal of Nursing and Health Science. 2017; 6(1), 61 -64.

13. Liu L.Q. \& Mehigan S. (2016). The Effects of Surgical Hand Scrubbing Protocols on Skin Integrity and Surgical Site Infection Rates: A Systematic Review. AORN J. May; 103(5):468-82. https://doi.org/10.1016/j.aorn.2016.03.003

14. Mahmoud, M. H., \& Assad, A. M. (2013). Surgical asepsis practices among or staff in king khalid hospital, Najran. International Journal of Current Research, 5(11), 3461 - 3473.

15. Alaaa-Eldeen TM, Saad AY, Elrefaee NM. Assessment of nurses' practices related to safety of intraoperative surgical patient undergoing general anesthesia. Journal of American Science. 2012;8(8):118-30.

16. Surgical Scrub, Gown and Glove Procedure. (2017). NHS Foundation Trust, 3, 1 - 16

17. Bahar Seifi, Sahbaei, F., Zare, M. Z., Abdoli, A., \& Heidari, M. (2016). A comparative study between povidione- iodine and manugel 85 on surgical scrub. Mater Sociomed. 2016; 28(5), 348 - 352. https://dx.doi.org/10.5455/msm.2016.28.348352 